\title{
Dialysable thyroxine index in the assessment of thyroid status
}

\author{
T. M. D. GIMLETTE \\ From the Isotope Laboratory, St. Thomas's Hospital, London
}

SYNOPSIS A method is described for assessing thyroid status by estimating plasma thyroxine and dialysable thyroxine and multiplying these two to give a dialysable thyroxine index.

Certain difficulties which sometimes invalidate other thyroid function tests are avoided. The techniques are relatively simple and clear differentiation between thyroid states can usually be made.

It has become widely accepted that thyroid status must be closely related to the concentration of free thyroxine in the plasma (Robbins and Rall, 1960; Sterling and Hegedus, 1962; Oppenheimer, Squef, Surks, and Hauer, 1963). Direct estimation of this concentration, which is of the order $0.1 \%$ of total thyroxine, has not so far been possible. However, by indirect methods using $\mathrm{I}^{131}$ thyronines as tracers, free thyroxine or the relative concentration of free thyroxine have been estimated (Robbins and Rall, 1957; Sterling and Hegedus, 1962; Osorio, Jackson, Gartside, and Goolden, 1962; Christensen, 1959).

A simple technique for estimating dialysable thyroxine has been described (Gimlette, 1964) and in the present study this has been combined with the estimation of plasma thyroxine (Ekins, 1960), the product giving a relative measure of free or available thyroxine, the dialysable thyroxine index.

\section{METHODS}

1 SIXTEEN-HOUR DIALYSABLE THYROXINE The method has been described (Gimlette, 1964). In outline, it consists in the estimation of the percentage of a tracer of $I^{131}$ thyroxine added to the plasma under investigation which is dialysed, during 16 hours at $37^{\circ} \mathrm{C}$., out of a small cellophane bag immersed in a sample of the same plasma in a test tube.

2 PLASMA THYROXINE The method described by Ekins (1960) was followed with the following modifications. Stock solution of $\mathrm{I}^{\mathbf{1 3 1}}$ thyroxine was prepared by adding the required quantity of $\mathrm{I}^{131}$ thyroxine (in $50 \%$ propylene glycol as obtained from the Radiochemical Centre, Amersham) to about $4 \mathrm{ml}$. of $2 \% \mathrm{HSA}$, leaving it half an hour, then shaking with Amberlite IRA 400 resin to remove free idoide (Owen, 1960). This stock solution was further diluted with normal saline if necessary. Samples,

Received for publication 20 July 1964. each of $4 \mathrm{ml}$., of serum or plasma from patients under investigation were used and one drop of diluted stock solution of $\mathrm{I}^{131}$ thyroxine was added to each before butanol extraction. The quantity of thyroxine needed to give adequate counts was less than $0 \cdot 1 \mu \mathrm{g} . / 100 \mathrm{ml}$. and this was ignored in subsequent calculations. After dissolving the extracted residue in $1 \mathrm{ml}$. of normal serum, $0.4 \mathrm{ml}$. of this serum was made up to $4 \mathrm{ml}$. and counted to estimate the percentage recovery of the butanol extraction, the rest of the serum being kept for electrophoresis. Before electrophoresis $I^{131}$ thyroxine stock solution was added to each of the aliquots of 'unknown' serum and to the standard sera. The same quantity (1-3 $\mu \mathrm{g}$. $/ 100 \mathrm{ml}$.) of thyroxine was added to each serum of a batch; this added thyroxine was therefore also ignored in the calculation. The result was calculated as follows:

Plasma thyroxine $=\frac{\text { Thyroxine in 'unknown' serum }}{\% \text { Thyroxine } \mathrm{I}^{131} \text { extracted with butanol }} \times \frac{100}{4}$

This estimation of thyroxine gives a value approximately $50 \%$ greater than chemical protein-bound iodine.

In some normal subjects small amounts of triodothyronine are present in the plasma and in hyperthyroidism the proportion may be quite high (Vanotti Beraud, and Dorta, 1961; Wellby and Hetzel, 1962). To investigate the effect of triodothyronine a number of plasma samples were investigated after the addition of $10 \mu \mathrm{g} . / 100 \mathrm{ml}$. of triodothyronine or thyroxine.

TABLE

ESTIMATED PLASMA THYROXINE, ( $\mu \mathrm{g} . \%$ )

Mean of Nine Estimations

\begin{tabular}{ll}
\hline Plasma & $10 \cdot 4$ \\
Plasma $+10 \mu \mathrm{g} . \%$ T.3 & $14 \cdot 4(+4 \cdot 0)$ \\
Plasma $+10 \mu \mathrm{g} . \%$ T.4 & $20 \cdot 2(+9 \cdot 8)$
\end{tabular}

It is clear that when a large proportion of the total hormone is triodothyronine, the effective available hormone will be underestimated. This also occurs with 
other techniques, including the estimation of chemical protein-bound iodine. The difficulty can be overcome by quantitative chromatographic techniques which are somewhat exacting for routine use, but it is probable that seriously misleading results from this cause will not occur often.

\section{RESULTS}

These are summarized in Figures 1 and 2. The patients investigated were referred for routine thyroid function studies. They were not specially selected for the tests described because they were straightforward cases, but there was, on the contrary, some bias towards selecting for study ill patients likely to give difficulty in diagnosis.

Thyroid status was assessed clinically with the aid of the clinical index (Wayne, 1960) and the myxoedema index (Wayne, 1962), by radioactive iodine studies in vivo, and by estimation of the red cell uptake of triodothyronine (Hamolsky, Stein, and Freedberg, 1957), and in some patients also by the triodothyronine suppression test, effect of thyroidstimulating hormone, estimation of B.M.R., chemical protein-bound iodine, or observation of the effect of a therapeutic trial.

Plasma thyroxine estimated in 83 euthyroid subjects without serious organic disease gave a mean value of $9.6 \pm 4.4 \mu \mathrm{g} . / 100 \mathrm{ml}$. ( \pm 2 S.D.s), corresponding to a protein-bound iodine value of $6.25 \pm 2.85 \mu \mathrm{g} . / 100 \mathrm{ml}$. Twenty-six duplicate

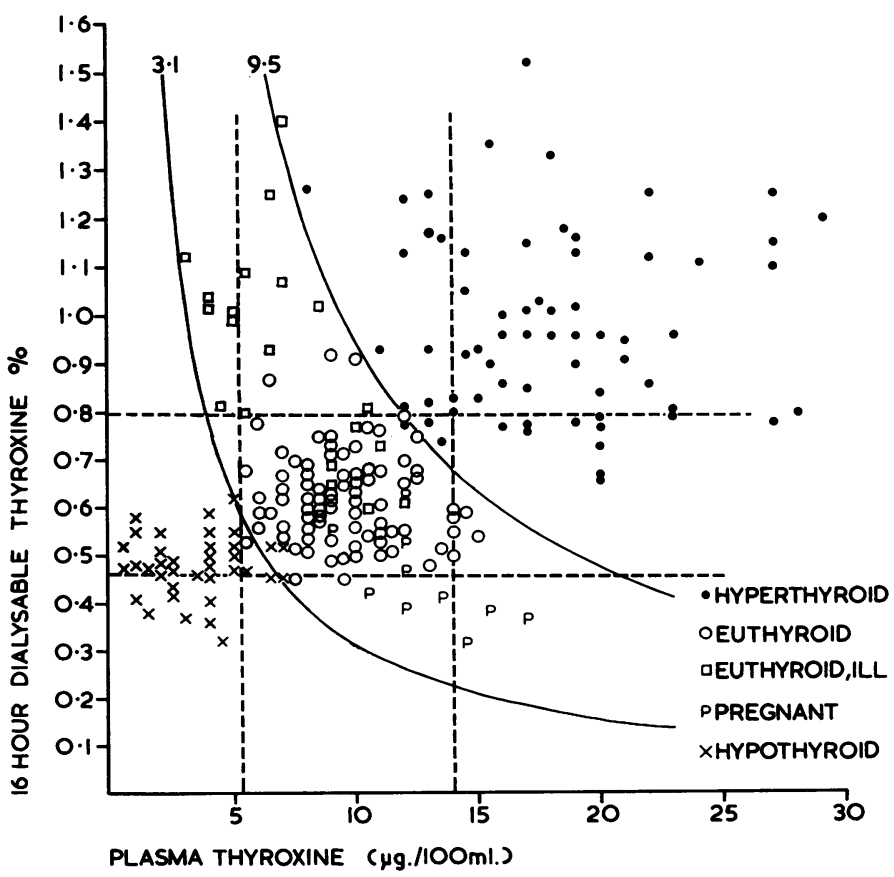

FIG. 1. Plasma thyroxine and 16-hour dialysable thyroxine. Broken lines indicate the normal range (mean $\perp$ 2 S.D.s) for plasma thyroxine and 16-hour dialysable thyroxine in 83 euthyroid subjects without serious organic disease. Curves indicate the normal range for dialysable thyroxine index in these euthyroid subjects.

FIG. 2. Dialysable thyroxine index in different groups of subjects. Horizontal lines indicate the normal range.

FIG. 1. 
In the same group this gave a mean of $6 \cdot 3 \pm 3 \cdot 2$. Among the euthyroid patients a subgroup has been distinguished of patients who were known to be seriously ill apart from any possible disorder of thyroid function. These ill patients were suffering from a variety of conditions including cardiac or renal failure, carcinoma, severe infection, cirrhosis, and 'collagen' diseases. In some of them it was found that plasma thyroxine was low while dialysable thyroxine was high (Fig. 1), the dialysable thyroxine index being normal $(6 \cdot 8 \pm 3.7)$ (Fig. 2). This finding is of special value since in ill patients such as these it is often difficult to assess thyroid status by the usual methods; radioiodine studies in vivo are sometimes difficult to interpret or anomalous, and the red cell uptake of triodothyronine is sometimes misleadingly high. Studies in some of these ill patients have shown decreased capacity of the thyroxine-binding globulin or of prealbumin or both, and these changes probably account for the combination of low plasma thyroxine and high dialysable thyroxine. Conversely, in pregnancy where binding capacity of thyroxine-binding globulin is high, a raised plasma thyroxine level, with proportionately lowered dialysable thyroxine level, was found in most of the patients studied (Figs 1 and 2). The possible effect of certain drugs, such as salicylate, which alter the functioning of thyroxine-binding proteins was not studied, but it seems likely that a reliable assessment of thyroid status would be given by the dialysable thyroxine index.

The technique for estimating the dialysable thyroxine index which has been described has certain advantages. No radioactive substance is given to the patient, who need not attend in person at all, although it is not suggested that this test, or any other, should replace an expert clinical appraisal. The test can be applied to patients in whom radioiodine studies in vivo are contraindicated, or in whom such studies would be invalidated for various reasons, particularly the administration of iodinecontaining substances. It also seems to be a reliable method of assessment in patients in whom the thyroxine-binding proteins have been altered by disease, pregnancy, or certain drugs. The procedures are more complicated than some of the simplest thyroid function tests, particularly studies with radioiodine in vivo, but they are not difficult, are reasonably reliable, and do not require the relatively exacting chemical technique needed for estimation of chemical protein-bound iodine. The test appears to give good differentiation between normal and abnormal thyroid status.

\section{REFERENCES}

Christensen, L. K. (1959). Scand. J. Lab. clin. Invest., 11, 326.

Ekins, R. P. (1960). Clin. chim. Acta, 5, 453.

Gimlette, T. M. D. (1964). J. clin. Path., 17, 58.

Hamolsky, M. W., Stein, M., and Freedberg, A. S. (1957). J. clin. Endocr., 17, 33.

Oppenheimer, J. H., Squef, R., Surks, M. I., and Hauer, H. (1963). J. clin. Invest., 42, 1769.

Osorio, C., Jackson, D. J., Gartside, J. M., and Goolden, A. W. G. (1962). Clin. Sci., 23, 525.

Owen, G. M. (1960). Phys. in Med. Biol., 5, 183.

Robbins, J., and Rall, J. E. (1957). Recent Progr. Hormone Res., 13, 161 .

(1960). Physiol. Rev., 40, 415

Sterling, K., and Hegedus, A. (1962). J. clin. Invest., 41, 1031.

Vanotti, A., Beraud, T., and Dorta, T. (1961). In Advances in Thyroid Research (4th International Goitre Conference, London, 1960), edited by R. Pitt-Rivers, p. 434. Pergamon Press, London.

Wayne, E. J. (1960). Brit. med. J., 1, 1.

(1962). Personal communication.

Wellby, M. L., and Hetzel, B. S. (1962). Nature (Lond.), 193, 752. 